Old Dominion University

ODU Digital Commons

\title{
Successfully Aging at Work or Successfully Working While Aging? The Importance of Older Workers' Psychological Well-Being
}

William P. Jimenez

wjimenez@odu.edu

Follow this and additional works at: https://digitalcommons.odu.edu/psychology_fac_pubs

Part of the Geropsychology Commons, and the Industrial and Organizational Psychology Commons

\section{Original Publication Citation}

Jimenez, W. P. (2020). Successfully aging at work or successfully working while aging? The importance of older workers' psychological well-being. Industrial and Organizational Psychology: Perspectives on Science and Practice, 13(3), 422-425. https://doi.org/10.1017/iop.2020.60

This Article is brought to you for free and open access by the Psychology at ODU Digital Commons. It has been accepted for inclusion in Psychology Faculty Publications by an authorized administrator of ODU Digital Commons. For more information, please contact digitalcommons@odu.edu. 
Successfully Aging at Work or Successfully Working While Aging?

The Importance of Older Workers' Psychological Well-Being

\author{
William P. Jimenez \\ Department of Psychology, Old Dominion University
}

\begin{abstract}
Author Note
William P. Jimenez (iD https://orcid.org/0000-0003-1141-4631

I have no known conflict of interest to disclose.

Correspondence concerning this article should be addressed to William P. Jimenez, Old Dominion University, Department of Psychology, Mills Godwin Building 250, Norfolk, VA 23529, United States. Email: wil.p.jimenez@gmail.com
\end{abstract}

This article has been published in a revised form in Industrial and Organizational Psychology: Perspectives on Science and Practice https://doi.org/10.1017/iop.2020.60. This version is free to view and download for private research and study only. Not for redistribution or re-use. (C) The Author(s) 2020. 


\section{Successfully Aging at Work or Successfully Working While Aging? The Importance of Older Workers' Psychological Well-Being}

Frank, 62, has been working at the same company for the past 32 years. His strong work ethic, subject-matter expertise, and continued excellent performance have saved him from several waves of layoffs and restructuring. Over the years Frank has become cynical. Gradually, many of Frank's close colleagues were let go, and he has had difficulty connecting with newer employees. Although he is not particularly happy at his job, Frank is determined to continue working for his employer until at least 66, which is when he can start collecting Social Security benefits without penalty.

By Kooij et al.'s (2020) definition, Frank is successfully aging at work. He is a competent employee who has the requisite knowledge, skills, and abilities to excel at his job. With regard to motivation, he is a hard worker, and he is motivated to continue working until at least normal retirement age. But is Frank thriving at work? His cynicism suggests that he is not. Thriving is characterized by vitality and learning (Porath et al., 2012). Because thriving indicates that an individual not only successfully engages in self-regulation through the acquisition of new knowledge and development of new skills, but also experiences a "zest for work" (Porath et al., 2012, p. 251), thriving is a sufficient but unnecessary condition for successful aging at work as defined by Kooij and colleagues. Thriving at work underscores the significance of employee health and well-being.

Considering that a competent and hard-working older employee who is committed to continue working yet is apathetic about — or, in Frank's case, has negative attitudes towardtheir job would be deemed successfully aging at work, I contend that what Kooij et al. call "successful aging at work" is more accurately described as "successfully working while aging" 
(i.e., maintaining optimal job performance and striving to continue working while aging). I believe that the focal article's model could be improved by formally incorporating older workers' psychological well-being into its definition of successful aging at work.

\section{Conceptualizing Psychological Well-Being: Not Just Happiness or Job Satisfaction}

How should psychological well-being be conceptualized? Some scholars have conceptualized it as happiness, satisfaction, or the presence of positive emotions coinciding with an absence of (or fewer) negative emotions (e.g., Diener, 1984). In industrial-organizational (IO) psychology, this conceptualization manifests itself in the happy-productive worker hypothesis (i.e., "happy employees exhibit higher levels of job-related performance behaviors than do unhappy employees"; Cropanzano \& Wright, 2001, p. 182). Findings from several empirical studies are consistent with the hypothesis (e.g., Staw \& Barsade, 1993; Taris \& Schreurs, 2009). But psychological well-being may be more than just happiness, experiencing few negative emotions, or job satisfaction.

According to Seligman (2011), psychological well-being comprises not only positive emotions (which subsume happiness and related constructs), but also engagement, positive relationships, meaning, and accomplishment (PERMA) — all of which are purportedly pursued as ends in themselves. Applied to the workplace, psychological well-being, in the context of the PERMA framework, looks like the following: frequently experiencing positive emotions (e.g., gratitude, pride; see Hu \& Kaplan, 2015) on the job; being energized by, absorbed in, and dedicated to one's work (see, e.g., Demerouti et al., 2001); having positive relationships with one's supervisor and coworkers (see, e.g., Colbert et al., 2016); perceiving that one's work is meaningful (see, e.g., Dik et al., 2013); and successfully accomplishing work-related goals and fulfilling work-related responsibilities (see, e.g., Van den Broeck et al., 2010). Although 
PERMA research is still in its infancy (Seligman, 2018), there is preliminary evidence that suggests this expanded conceptualization of psychological well-being is indeed applicable to an individual's experience at work (e.g., Watanabe et al., 2018).

\section{Older Workers' Psychological Well-Being is Important}

Kooij et al. (2020) discussed the importance of self-regulation behavior in the pursuit of enhancing person-environment (P-E) fit to facilitate the maintenance or recovery of job-related knowledge, skills, abilities and motivation to continue successfully working. In the context of PERMA, those who are successfully aging at work should experience accomplishment, because their self-regulation behaviors lead to P-E fit (and, ultimately, enhanced job performance), and work engagement, which is predictive of retirement among older workers (e.g., de Wind et al., 2017). Thus, these two facets of psychological well-being are implied in Kooij and colleagues' model of successful aging at work, but what about the other PERMA dimensions?

Kooij et al. (2020) mentioned emotions, positive relationships, and meaning — but did so only in passing (viz., self-regulation of emotions, managers' role in supporting older workers and effecting a climate for age diversity, finding new meaning in work as a form of goal disengagement). Prior research has demonstrated that these dimensions of psychological wellbeing are especially important later in life. Experiencing positive emotions is linked to decreased morbidity and improved health later in life, and it may ameliorate the deleterious physiological effects stressors have on older adults (Ong, 2010). In the workplace, positive emotions serve as personal resources that enable workers to cope with job demands (Fredrickson, 2000), and they may equip older workers with the capacity to persevere-even in situations that invoke stereotype threat (e.g., fast-paced work environments that make the stereotype of job performance declining with age—see Posthuma \& Campion, 2009—salient). 
Additionally, loneliness later in life is positively associated with feelings of helplessness and negatively associated with seeking emotional support (Hawkley \& Cacioppo, 2007). In this commentary's opening scenario, Frank's cynicism might be, in part, attributable to losing valued, positive work relationships as a result of his organization downsizing and his difficulty establishing relationships with his new coworkers. Indeed, social support at work has been identified as an important predictor of burnout (Halbesleben, 2006). Also, engaging in meaningful work is especially important to older workers, who are driven more by intrinsic motives (e.g. opportunities to develop younger generations) rather than extrinsic motives (e.g., career advancement; Kooij et al., 2015). Moreover, findings from a recent meta-analysis suggest that meaningful work is strongly related to job attitudes and moderately related to turnover intentions and more general outcomes, such as life satisfaction and general health (Allan et al., 2019).

\section{Concluding Remarks}

I recommend revising the definition of successful aging at work to include not only the maintenance or recovery of job-related knowledge, skills, and abilities and the motivation to continue working, but also psychological well-being. This view is consistent with the recommendation that I-O psychology adopt more humanistic ideals (Lefkowitz, 2019). In addition to evaluating whether older workers are able to competently perform their jobs, we should care about whether they experience positive emotions, engagement, positive relationships, meaning, and accomplishment. Recently, researchers have begun to develop measures of work-related PERMA (e.g., Kern, 2014; Kun et al., 2017) and PERMA interventions for employees (e.g., Neumeier et al., 2017). Even before psychometrically sound measures of PERMA are made available, it would be, from the perspective of diversity, equity, 
inclusion, and occupational health, prudent of organizations and I-O psychologists to prioritize older workers' psychological well-being as much as their productivity-especially if we expect these workers to remain longer in the workforce. 


\section{References}

Allan, B. A., Batz-Barbarich, C., Sterling, H. M., \& Tay, L. (2019). Outcomes of meaningful work: A meta-analysis. Journal of Management Studies, 56(3), 500-528. https://doi.org/10.1111/joms.12406

Colbert, A. E., Bono J. E., \& Purvanova, R. K. (2016). Flourishing via workplace relationships: Moving beyond instrumental support. Academy of Management Journal, 59(4), 1199_ 1223. https://doi.org/10.5465/amj.2014.0506

Cropanzano, R., \& Wright, T. A. (2001). When a "happy” worker is really a "productive" worker: A review and further refinement of the happy-productive worker thesis. Consulting Psychology Journal: Practice and Research, 53(3), 182-199. https://doi.org/10.1037/1061-4087.53.3.182

Demerouti, E., Bakker, A. B., de Jonge, J., Janssen, P. P. M., \& Schaufeli, W. B. (2001). Burnout and engagement at work as a function of demands and control. Scandinavian Journal of Work, Environment \& Health, 27(4), 279-286. https://doi.org/10.5271/sjweh.615

Diener, E. D. (1984). Subjective well-being. Psychological Bulletin, 95(3), 542-575. https://doi.org/10.1037/0033-2909.95.3.542

Dik, B. J., Byrne, Z. S., \& Steger, M. F. (Eds.). (2013). Purpose and meaning in the workplace. American Psychological Association. https://doi.org/10.1037/14183-000

De Wind, A., Leijten, F. R. M., Hoekstra, T., Geuskens, G. A., Burford, A., \& van der Beek, A. J. (2017). “Mental retirement?” Trajectories of work engagement preceding retirement among older workers. Scandinavian Journal of Work, Environment, \& Health, 43(1), 34 41. https://doi.org/10.5271/sjweh.3604 
Fredrickson, B. L. (2000). Why positive emotions matter in organizations: Lessons from the broaden-and-build model. Psychologist-Manager Journal, 4(2), 131-142. https://doi.org/10.1037/h0095887

Halbesleben, J. R. B. (2006). Sources of social support and burnout: A meta-analytic test of the conservation of resources model. Journal of Applied Psychology, 91(5), 1134-1145. https://doi.org/10.1037/0021-9010.91.5.1134

Hawkley, L. C., \& Cacioppo, J. T. (2007). Aging and loneliness: Downhill quickly? Current Directions in Psychological Science, 16(4), 187-191. https://doi.org/10.1111/j.14678721.2007.00501.x

Hu, X., \& Kaplan, S. (2015). Is “feeling good” good enough? Differentiating discrete positive emotions at work. Journal of Organizational Behavior, 36(1), 39-58. https://doi.org/10.1002/job.1941

Kern, M. L. (2014). The workplace PERMA profiler. http://www.peggykern.org/uploads/5/6/6/7/56678211/workplace_perma_profiler_102014 .$p d f$

Kooij, D. T. A. M., Tims, M., \& Kanfer, R. (2015). Successful aging at work: The role of job crafting. In P. M. Bal, D. T. A. M. Kooij, \& D. M. Rousseau (Eds.), Aging workers and the employee-employer relationship (pp. 145-161). Springer.

Kooij, D. T. A. M, Zacher, H., Wang, M., \& Heckhausen, J. (2020). Successful aging at work: A process model to guide future research and practice. Industrial and Organizational Psychology: Perspectives on Science and Practice, 13(3). Advance online publication. https://doi.org/10.1017/iop.2020.1 
Kun, Á., Balogh, P., \& Krasz, K. G. (2017). Development of the Work-Related Well-Being Questionnaire based on Seligman's PERMA model. Periodica Polytechnica Social and Management Sciences, 25(1), 56-63. https://doi.org/10.3311/PPso.9326

Lefkowitz, J. (2019). The conundrum of industrial-organizational psychology. Industrial and Organizational Psychology: Perspectives on Science and Practice, 12(4), 473-478. https://doi.org/10.1017/iop.2019.114

Neumeier, L. M., Brook, L., Ditchburn, G., \& Sckopke, P. (2017). Delivering your daily dose of well-being to the workplace: A randomized controlled trial of an online well-being programme for employees. European Journal of Work and Organizational Psychology, 26(4), 555-573. https://doi.org/10.1080/1359432X.2017.1320281

Ong, A. D. (2010). Pathways linking positive emotion and health in later life. Current Directions in Psychological Science, 19(6), 358-362. https:/doi.org/10.1177/0963721410388805

Porath, C., Spreitzer, G., Gibson, C., \& Garnett, F. G. (2012). Thriving at work: Toward its measurement, construct validation, and theoretical refinement. Journal of Organizational Behavior, 33(2), 250-275. https://doi.org/10.1002/job.756

Posthuma, R. A., \& Campion, M. A. (2009). Age stereotypes in the workplace: Common stereotypes, moderators, and future research directions. Journal of Management, 35(1), 158-188. https://doi.org/10.1177/0149206308318617

Seligman, M. (2018). PERMA and the building blocks of well-being. Journal of Positive Psychology, 13(4), 333-335. https://doi.org/10.1080/17439760.2018.1437466

Seligman, M. E. P. (2011). Flourish: A visionary new understanding of happiness and wellbeing. Simon \& Schuster. 
Staw, B. M., \& Barsade, S. G. (1993). Affect and managerial performance: A test of the sadderbut-wiser vs. happier-and-smarter hypotheses. Administrative Science Quarterly, 38(2), 304-331. https://doi.org/10.2307/2393415

Taris, T. W., \& Schreurs, P. J. G. (2009). Well-being and organizational performance: An organizational-level test of the happy-productive worker hypothesis. Work \& Stress, 23(2), 120-136. https://doi.org/10.1080/02678370903072555

Van den Broeck, A., Vansteenkiste, M., De Witte, H., Soenens, B., \& Lens, W. (2010). Capturing autonomy, competence, and relatedness at work: Construction and initial validation of the Work-related Basic Need Satisfaction scale. Journal of Occupational and Organizational Psychology, 83(4), 981-1002.

https://doi.org/10.1348/096317909X481382

Watanabe, K., Kawakami, N., Shiotani, T., Adachi, H., Matsumoto, K., Imamura, K., Yamagami, F., Fusejima, A., Muraoka, T., Kagami, T., Shimazu, A., \& Kern, M. L. (2018). The Japanese workplace PERMA-profiler: A validation study among Japanese workers. Journal of Occupational Health, 60(5), 383-393. https://doi.org/10.1539/joh.2018-0050-OA 